\title{
LA OBLIGACIÓN DE ALIMENTAR \\ A LOS HIJOS MENORES Y LA LIMITACIÓN \\ TEMPORAL DE LA MISMA POR APLICACIÓN \\ DE LO DISPUESTO EN EL PÁRRAFO PRIMERO \\ DEL ARTÍCULO 148 DEL CÓDIGO CIVIL \\ (COMENTARIO AL AUTO DEL TRIBUNAL \\ CONSTITUCIONAL 301/2014, DE 16 DE DICIEMBRE)
}

Time Limits to Minor's Maintenance Obligations under Article 148 of the Spanish Civil Code

\section{CRISTINA DE AMUNÁTEGUI RODRÍGUEZ \\ Profesora Titular de Derecho Civil \\ Universidad Complutense de Madrid}

\author{
Recepción: 30/07/2015 \\ Aceptación después de revisión: 03/09/2015 \\ Publicación: 27/11/2015
}

I. Planteamiento general. II. Obligación legal de alimentos. Especial REFERENCIA A LOS DEBIDOS POR LOS PADRES A SUS HIJOS MENORES. III. EFECTOS DE LA APLICACIÓN DEL 148.1 DEL CÓDIGO CIVIL A LAS RECLAMACIONES ALIMENTARIAS. IV. MOTIVOS DE INADMISIÓN A TRÁMITE DEL RECURSO: 1. Cuestión notoriamente infundada. 2. Análisis de la viabilidad de la duda de constitucionalidad. V. ¿PosIBILIDAD DE DICTAR UNA SENTENCIA INTERPRETATIVA? VI. OTROS POSIBLES EFECTOS DERIVADOS DE LA FALTA DE PRESTACIÓN DE ALIMENTOS A LOS HIJOS MENORES. VII. BREVES CONCLUSIONES. BIBLIOGRAFÍA.

\section{RESUMEN}

El artículo 148, párrafo $1 .^{\circ}$ del Código Civil establece una limitación temporal a la exigibilidad de alimentos, disponiendo que no se abonarán sino desde la interposición de la demanda. La falta de efectos retroactivos, afirmada reiteradamente por los Tribunales, choca con el contenido de la obligación de los progenitores de alimentar a los hijos durante toda su minoría de edad, consagrada en el artículo 39. 3 de la Constitución, y con el respeto al principio del interés del menor. El Auto 30/2014 no admite a trámite la cuestión planteada sobre la posible inconstitucionalidad del mencionado párrafo del Código, en relación con el texto de la Constitución.

PALABRAS CLAVE: Menores; alimentos; retroactividad. 


\begin{abstract}
When ruling that maintenance obligations will only be payable from the date of the demand, article 148.1 of the Spanish Civil Code sets a clear temporal limit on their enforceability. This lack of retroactive effects, that has been consistently confirmed by the jurisprudence, clashes on the one hand, with the parental obligation to maintain children under the age of eighteen, established in article 39.3 of the Spanish Constitution, and, on the other hand, with the respect for the principle of the best interest of the child. The Decree No. 30/2014, has rejected the admission of a question on the constitutionality of article 148.1 CC.
\end{abstract}

KEY WORDS: Minors; maintenance; retroactivity.

\title{
I. PLANTEAMIENTO GENERAL ${ }^{1}$
}

El Auto 301/2014, de 16 de diciembre, objeto de este comentario, no permite al Tribunal llegar a pronunciarse sobre la posible inconstitucionalidad del párrafo primero del artículo 148 del Código Civil cuando expresamente dispone: «La obligación de dar alimentos será exigible desde que los necesitare, para subsistir, la persona que tenga derecho a percibirlos; pero no se abonarán sino desde la fecha en que se interponga la demanda».

Es precisamente el inciso correspondiente al momento en que deben abonarse los alimentos lo que plantea dudas de constitucionalidad al Juzgado de Primera Instancia n. 20 de Palma de Mallorca, por la posible infracción de lo dispuesto en el artículo 39.3 de la Constitución española al establecer la obligada asistencia a los hijos durante su minoría de edad. Se recaba al respecto un pronunciamiento al Tribunal «sobre si la obligación de los progenitores de prestar alimentos a los hijos menores, que dimana del artículo 39.3 CE, se extiende a toda su minoría de edad, o si por el contrario dicha obligación solo es exigible a partir de la fecha en que el representante legal del menor interpone la demanda correspondiente».

La aplicación de la regla prevista por la norma a las pretensiones de alimentos para los hijos menores - no solo en el marco de los procesos

${ }^{1}$ Este trabajo se enmarca entre los resultado del Proyecto de Investigación financiado por el MINECO, DER2011-22469, bajo el título «Negocios jurídicos de familia: la autonomía de la voluntad como cauce de solución de las disfunciones del sistema». Agradezco a mi compañero Tomás Cano Campos la lectura previa de este artículo y sus valiosas indicaciones y sugerencias. 
matrimoniales ${ }^{2}$, sino también en los de reclamación de filiación ${ }^{3}-$ conduce en ocasiones a resultados injustos, al carecer el pronunciamiento recaído en el proceso de efecto retroactivo, lo que determina una limitación o recorte en el cumplimiento para el progenitor deudor del contenido de la obligación constitucional, dejando sin efecto la protección integral recogida en el mencionado texto ${ }^{4}$.

Lamentablemente la cuestión no llega a salvar el férreo control previo de admisión considerándose, al amparo de lo dispuesto en el artículo 37.1 de la Ley Orgánica del Tribunal Constitucional, notoriamente infundada, por lo que no es posible contar con un análisis en profundidad de la misma, más allá de unas consideraciones generales, basadas en su mayoría en la opinión sustentada por el fiscal, y, eso sí, de las valiosas argumentaciones recogidas en el voto particular formulado por el magistrado Juan Antonio Xiol Ríos al estimar conveniente una mayor reflexión sobre el contenido y efectos de la norma que hubieran aconsejado su admisión a trámite, manifestando que «a mi juicio era inexcusable, en la mejor tradición de la jurisprudencia sobre protección de los derechos constitucionales, un análisis más profundo del juicio de proporcionalidad $»^{5}$.

${ }^{2}$ En este supuesto concreto se trata de la reclamación de alimentos formulada por el padre contra la madre en un proceso de modificación de medidas, desde el momento en que el hijo menor se traslada a vivir con él.

${ }^{3}$ Si bien en el caso de la filiación puede tener más justificación la negación de efectos retroactivos respecto de un periodo en el que el progenitor puede ignorar la relación de filiación, sin existir un flagrante incumplimiento del deber de asistencia a los hijos menores de los que se desconoce la paternidad.

${ }^{4}$ El propio juez de Primera Instancia entiende que, al tratarse de una regla preconstitucional, podría considerarse tácitamente derogada, pero que la constante revocación de sus decisiones en ese sentido por la Audiencia le obliga a plantear la cuestión de inconstitucionalidad.

En mi opinión habría que valorar que el párrafo inicial del artículo 148 CC no solo es preconstitucional, sino que forma parte de la redacción originaria del Código, pensada para un tiempo en el que no existían acciones de filiación, ni procedimientos de divorcio (supuestos en los que mayoritariamente se plantea el problema objeto del Auto), ni principios como el del interés superior del menor revestían la trascendencia que presentan en la actualidad como criterios de interpretación de las normas. No ahondaré en esta cuestión pues en ningún momento se refieren a ella los pronunciamientos recaídos sobre la materia, pero quiero destacar su importancia como parte de las circunstancias que rodean la interpretación de las normas según el tiempo en que han de ser aplicadas al que se refiere el Código Civil.

${ }^{5}$ Lo considera, con palabras textuales, «una pena», BERCOvitz RodRíGUEZ-CANO, R. (2015): «Un voto particular interesante en materia de alimentos», Revista Doctrinal Aranzadi Civil-Mercantil n. ${ }^{\circ}$ 1/2015 parte Comentario (BIB 2015\718), «porque era la 
Partiendo el Tribunal de la afirmación de que el planteamiento adolece de falta de argumentos que conecten el artículo 39. 3 CE con la limitación temporal de su exigibilidad, asumiendo las consideraciones del fiscal, y no con la existencia o no del deber de alimentos a los hijos menores, se trataría de determinar si la solución del legislador responde a los intereses en presencia, con prevalencia del destacado interés del menor. Tal consideración no supera la valoración de la razonabilidad y proporcionalidad, pues, en palabras del Auto, «en los términos en que la duda de constitucionalidad se plantea, sí resulta que la retroactividad de los alimentos facilitaría procesalmente el resarcimiento del progenitor que cumplió su obligación ex artículo 154.1 del Código Civil como vía para reclamar la deuda al progenitor incumplidor. Pero no es inmediato cómo dicha retroactividad sirve al interés superior del menor: los alimentos no se orientarían a la asistencia al menor, el fin del artículo 39. $3 \mathrm{CE}$, pues el menor ya fue asistido y sus necesidades de todo orden fueron cubiertas. Y si no fueron, los alimentos reclamados retroactivamente no le servirían para cubrirlas ya $»^{6}$.

$\gg$ A mayor abundamiento - prosigue el Tribunal - , la norma cuestionada parece superar el juicio de ponderación con otros intereses, en concreto, el de los progenitores, que aun siendo de menor rango con relación al menor, deben ser tomados en consideración (STC 185/2012, de 27 de octubre, FJ 4, entre otras). Respecto al progenitor custodio la norma no es excluyente, pues nada le impide formular demanda en reclamación de alimentos tan pronto como nace la obligación. Respecto al progenitor no custodio, tampoco es excluyente pues puede cumplir voluntariamente su obligación desde que esta nace y, en los supuestos de cumplimiento forzoso, una delimitación temporal de la exigibilidad de los alimentos parece proporcionada para evitar una solución de pendencia, difícilmente compatible con el principio de seguridad jurídica (art. 9.3 CE)».

Ciertamente se trata de una materia sobre la que existe una Jurisprudencia uniforme que extiende lo previsto en el artículo 148.1 CC a cuantas obligaciones de alimentos resuelven los Tribunales, circunstan-

ocasión para poner remedio a una norma que, al menos, no debería extenderse a los alimentos de los padres respecto a los hijos menores de edad».

${ }^{6}$ Como ya he apuntado, el voto particular se aleja de este planteamiento exigiendo que «no solo se constatara que esta limitación temporal persigue el fin de evitar situaciones de inseguridad jurídica y que este es legítimo, sino, además, que la restricción operada es necesaria, que es la idónea para la consecución de ese fin y que no existen otros medios menos incisivos o restrictivos de los derechos del niño para su consecución». 
cia que puede llegar a dificultar la admisión de la cuestión de inconstitucionalidad, por lo que el proponente sostiene que el supuesto requiere una solución especial y no la general, doble posible interpretación que es rechazada por el Tribunal apelando a la vocación general del precepto. Es indiscutible, igualmente, que existen argumentos que avalan la postura mantenida por los jueces sobre la limitación temporal de la reclamación de alimentos y que son barajados con asiduidad por las sentencias que se ocupan de la cuestión. Lo es, del mismo modo, que pueden reconocerse algunas vías por las que el progenitor que cumple puede reclamar al que incumplió, es indudable.

Pero hay que tener en cuenta, también, que el rigor de los planteamientos que acompañan a la regulación de la obligación legal de alimentos entre parientes no siempre encajan adecuadamente en otros tipos de alimentos, especialmente los debidos a los hijos menores, en los que se entremezclan cuestiones diversas que precisan que, cuanto menos, se pudiera reflexionar más por el Tribunal sobre este particular admitiendo a trámite la cuestión planteada.

Por el contrario, no parece suficiente afirmar que no existen argumentos que conecten el artículo 39. 3 CE con la limitación temporal que surge de la aplicación del precepto enjuiciado, pues resulta indudable que los efectos que determina la limitación de la norma acortan una obligación que debe mantenerse durante toda la minoría de edad y liberan en muchos casos al progenitor del seguimiento de un deber impuesto por la Constitución cuyo beneficiario directo es el hijo.

Por otra parte, el Auto parece atender más a los intereses de los progenitores, a las relaciones entre acreedor y deudor respecto de los posibles pagos debidos y satisfechos por el otro, elevando ese interés, en mi opinión, por encima del que corresponde al menor que, sin duda posible al respecto, cuando recibe alimentos solo de uno de los padres estará en una situación de clara desventaja a cuando pueda percibirlos de los dos. El Tribunal se acerca en exceso a los argumentos que acompañan al tratamiento de la cuestión en el ámbito de la obligación legal de alimentos entre parientes, postergando el razonamiento del incumplimiento del mandato constitucional, lo que podría haberse resuelto, o al menos llegar a haberlo estudiado con detenimiento, mediante una sentencia interpretativa que fijase una línea de entendimiento acorde con la finalidad de los alimentos debidos a los hijos menores por imperativo constitucional y que afectase a la Jurisprudencia del Tribunal Supremo. No obstante, siguiendo las palabras del Fiscal General del Estado, fijar la solución aplicable no es la finalidad de la cuestión de inconstitucionalidad, proponiendo la inadmisión de la cuestión. 
Las cuestiones apuntadas serán analizadas en este comentario, si bien con carácter previo llevaré a cabo unas consideraciones generales sobre la obligación de alimentos, especialmente en el aspecto relativo al deber de alimentar a los hijos, y las consecuencias de la aplicación indiscriminada de lo dispuesto en el párrafo primero del artículo 148 CC.

\section{OBLIGACIÓN LEGAL DE ALIMENTOS. ESPECIAL REFERENCIA A LOS DEBIDOS POR LOS PADRES A SUS HIJOS MENORES}

Son muchas las posibles obligaciones de prestar alimentos que se contemplan en el ordenamiento civil, algunas de ámbito contractual y otras muchas de origen legal.

En principio, al amparo de lo dispuesto en el artículo 1795 CC, la regla enjuiciada no es de aplicación a las prestaciones alimenticias que tengan un origen convencional, en las que no existe problema alguno en reclamar los alimentos no satisfechos, incluyendo «el abono de los devengados con anterioridad a la demanda» ${ }^{7}$. Esta regulación permite ya plantear alguna duda respecto de las argumentaciones del Tribunal, pues es difícil justificar que si la fuente de la obligación es un contrato, los efectos de su cumplimiento se vean garantizados más que si su origen es una norma de rango constitucional. Si uno de los razonamientos barajados por el Auto con el fin de contrastar la proporcionalidad de la norma reside en afirmar que «en los supuestos de cumplimiento forzoso, una delimitación temporal de la exigibilidad de los alimentos parece proporcionada para evitar una situación de pendencia, difícilmente compatible con el principio de seguridad jurídica», su fuerza parece quedar algo desdibujada cuando el propio Código salva de esa limitación temporal otro tipo de obligaciones alimenticias cuya reclamación no parece comprometer la seguridad jurídica.

Puede decirse que en muchos casos la negación de efectos retroactivos en la reclamación de alimentos deviene de la coyuntura de que el alimentante podía hasta desconocer su obligación que, si bien existe desde que tiene lugar la situación de necesidad, exige un reconocimien-

7 Así, Echevarría de RADA, M. a T. (2011): El contrato de alimentos en el Código Civil, Universidad Rey Juan Carlos, p. 133; CoвACHo Gómez, J. A. (1990): La deuda

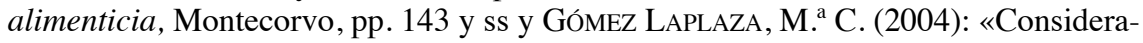
ciones sobre la nueva regulación del contrato de alimentos», Revista de Derecho Privado, marzo-abril 2004, pp. 163 y 171 y ss. 
to legal. No obstante, esta circunstancia que, evidentemente, no está presente en el caso de los alimentos convencionales, tampoco lo estará en aquellas que surgen de la filiación o de la patria potestad, como seguidamente se verá, pues se trata de deberes respecto de los que no puede alegarse ese desconocimiento previo que preside la interpretación de algunas reglas de los alimentos entre parientes.

Dentro del amplio concepto de las obligaciones legales de alimentos, caracterizadas por la Jurisprudencia como «una de las de mayor contenido ético del ordenamiento jurídico ${ }^{8}$, existen diferentes tipos basados en relaciones de parentesco, orígenes y fundamentos varios, y en los que la «obligación» de alimentar a otro no siempre está independizada de las reglas jurídicas que disciplinan su fuente ${ }^{9}$.

La aparente simplicidad de la obligación de alimentar a un hermano, que requiere los presupuestos de la necesidad del acreedor y posibilidad del deudor, que surge como tal cuando se reclama, pudiendo ni siquiera conocerla el alimentante, cuadra perfectamente con una regla limitativa de su exigencia temporal como es el párrafo primero del artículo $148 \mathrm{CC}$, de modo que el obligado cumple desde que conoce que es deudor, pareciendo contrario al principio de seguridad jurídica la reclamación de pensiones con efecto retroactivo y cobrando plena legitimidad la regla in praeteritum non vivitur ${ }^{10}$. Es evidente que, hasta el momento de la reclamación judicial, seguida de la sentencia correspondiente, «de algo habrá vivido el reclamante», habrá cubierto sus necesidades vitales de cierto modo, y sería injusto, al tiempo que no adecuado con el carácter de la prestación, permitirle percibir cuantía alguna correspondiente a ese periodo. Supondría, como tantas veces se dice, «una carga insoportable» para el alimentante cuando, precisamente, la obligación legal se dispone para atender a las necesidades presentes y futuras del reclamante, pero no las pasadas.

Ahora bien, he utilizado deliberadamente el término «aparente simplicidad», porque, incluso en este supuesto extremo, no habría posibilidad de repetir los alimentos prestados antes de la reclamación judicial

${ }^{8}$ Palabras recogidas, entre otras, en STS de 5 de octubre de 1993 (RJ 1993\7464).

${ }^{9}$ Respecto del fundamento de las distintas obligaciones de alimentos, ver RIBOT IguALADA, J. (1998): «El fundamento de la obligación legal de alimentos», Anuario de Derecho Civil, julio-septiembre de 1998, pp. 1105 y ss., en especial pp. 1130 y ss.

${ }^{10}$ Citando los términos de Delgado Echeverría, J. (1991): en Comentario del Código Civil, Ministerio de Justicia, T. I, p. 535, a quien sigue la doctrina que se ha ocupado del particular, la regla se explicaba «en el Derecho común europeo, por no preexistir, propiamente una obligación, sino quedar constituida esta ex officio iudicis y, por tanto, solo desde el momento en que se pidió la interposición de este oficio». 
que se consideran satisfechos en cumplimiento voluntario de una obligación y no por oficio de piedad ${ }^{11}$. Es decir, si se cumple voluntariamente con la prestación alimentaria se está asumiendo ya la presencia o realidad de la misma, atendiendo al criterio de que surgió cuando tuvieron lugar sus presupuestos de necesidad de acreedor y posibilidad de deudor; mientras que si no se cumple todavía - aun cuando en teoría tales presupuestos ya hubieran determinado su exigibilidad - tan solo queda obligado el deudor a los pagos posteriores a la presentación de la demanda, momento en el que la prestación deviene exigible.

No obstante, en otros casos el contenido y extensión de los alimentos puede variar sustancialmente, por ejemplo, en el caso del matrimonio, pudiendo quedar subsumidos cuando existe convivencia dentro de la mayor amplitud de la obligación de levantamiento de las cargas familiares (ex art. $1318 \mathrm{CC})^{12}$; convirtiéndose en una prestación alimentaria sin más en caso de separación; e incluso llegando a desaparecer en el supuesto de divorcio, con independencia de cuestionar ahora si la pensión compensatoria o la atribución de la vivienda familiar tengan o no similitudes con una obligación de alimentos.

En el caso de los hijos menores la cuestión se presenta, además, con una añadida dimensión constitucional, por cuanto dispone el artículo 39. 3 CE: «Los padres deben prestar asistencia de todo orden a los hijos habidos dentro o fuera del matrimonio, durante su minoría de edad y en los demás casos en que legalmente proceda $\gg^{13}$. Por otra parte, el apartado 2 de la norma comienza imponiendo una obligación a los poderes públicos disponiendo que «aseguran» la protección integral de los hijos. Esa garantía instrumental supone, en sentir de la doctrina, la ne-

${ }^{11}$ Otra cuestión, no exenta de problemas, sería la posibilidad de que el alimentista pudiera reclamar daños y perjuicios por el incumplimiento deliberado del alimentante previo a la reclamación judicial, extremo en el que me detendré más adelante. Por todos Delgado, ob. cit., p. 536.

${ }^{12}$ Que, atendiendo al contenido del artículo $1362,1^{\circ}$ del CC se extiende a la alimentación, educación y atenciones de previsión «acomodadas a los usos y circunstancias de la familia».

${ }^{13}$ En el mencionado voto particular formulado por el magistrado Xiol Ríos se lleva a cabo un detallado análisis de la jurisprudencia constitucional sobre el artículo $39 \mathrm{CE}$, fijando sus principales notas, con cita de pronunciamientos al respecto, en ser la concreción del interés superior del menor, que debe inspirar los procedimientos matrimoniales y de familia, y en imponer a los padres la obligación de alimentar, independientemente de cualquier otra consideración. Especialmente interesante es la cita de la STC 33/2006, en la que se menciona la obligación de los padres de prestar asistencia de todo tipo a sus hijos, por imperativo constitucional, asistencia que incluye la contribución a alimentos. 
cesidad de que los poderes públicos desplieguen «las actividades necesarias para que la asistencia resulte efectiva, bien porque se obligue a los padres a prestarla, bien porque estas organizaciones públicas se subroguen a costa de los padres, si tuvieran medios económicos, o a cargo de sus presupuestos, en esa obligación» ${ }^{14}$.

El deber de alimentar a los hijos que disciplina la norma mencionada se desarrolla durante toda su minoría de edad ${ }^{15}$, lo que casa mal con la limitación temporal que surge de la aplicación del artículo 148.1 CC $\mathrm{y}$, atendiendo a argumentos manejados por el Tribunal Supremo, se trata de «deberes insoslayables inherentes a la filiación».

El precepto se completa con otros como el artículo $110 \mathrm{CC}$, por el que los alimentos se consideran surgidos la filiación, con independencia de ostentar o no la patria potestad, el artículo $154 \mathrm{CC}$, que los integra en el contenido de la patria potestad, o, los ya mencionados, artículos 1318 y $1362 \mathrm{CC}$ al incluir el concepto dentro del levantamiento de las cargas familiares. En todos estos supuestos la prestación alimentaria trasciende de los rígidos parámetros que disciplinan los alimentos entre parientes para establecer una obligación no ceñida a la situación de necesidad, sino acomodada a los usos y circunstancias de la familia y que, por otra parte, queda reforzada en el sentido de que incumbe a ambos progenitores, haciendo abstracción de que hayan quedado cubiertas las necesidades básicas del menor ${ }^{16}$.

${ }^{14}$ En términos de Gálvez Montes, F. (2001): en Comentarios a la Constitución, Garrido de Falla, F. (Dir.), 3. ${ }^{\text {a }}$ edic. Civitas, p. 853.

${ }^{15}$ Incluso planteándose la doctrina su posible asistencia en un momento anterior al nacimiento, de lo que existe reflejo en el Código en el supuesto de los alimentos que puede reclamar la viuda encinta previstos en el artículo 964, precepto preconstitucional que no exige situación de necesidad al considerarse que tales alimentos participan de la naturaleza de las cargas familiares en toda su extensión. En relación con el artículo 39 CE, ver GómEZ, Y. (1990): Familia y matrimonio en la Constitución de 1978, Congreso de los Diputados, p. 335, afirmando que tal obligación comienza antes incluso del nacimiento, especialmente para la madre.

${ }^{16}$ No solo no está sujeta al parámetro de la necesidad del hijo, sino tampoco al de la posibilidad del alimentante, pues al progenitor le incumbe la obligación con independencia de su situación económica. Lo más que se admite por parte de los tribunales es llegar a declarar la suspensión de la obligación. En este sentido la STS 14 de octubre de 2014 (RJ 2014\4754), permite la suspensión de alimentos al progenitor ingresado en prisión, fijando la siguiente doctrina: «La obligación de pagar alimentos a los hijos menores no se extingue por el solo hecho de haber ingresado en prisión el progenitor que debe prestarlos si al tiempo no se acredita la falta de ingresos o de recursos para poder hacerlos efectivos». Ver los comentarios de Costas RodaL, L. (2015): «Novedades jurisprudenciales en materia de suspensión de la obligación de pagar alimentos a los hijos menores por ingreso en prisión del progenitor alimentante», Revista Doctri- 
Por otra parte, para los supuestos en los que se rompa la convivencia familiar los alimentos a los hijos van incluidos dentro de las previsiones del artículo 93 del CC: «El juez, en todo caso, determinará la contribución de cada progenitor para satisfacer los alimentos y adoptará las medidas convenientes para asegurar la efectividad y acomodación de las prestaciones a las circunstancias económicas y necesidades de los hijos en cada momento».

Resulta de este modo que, si bien puede haber relación entre las diferentes prestaciones alimentarias, las debidas a los hijos menores gozan de unos caracteres propios y específicos que no encajan siempre en el molde de la regulación de la obligación legal de los artículos 142 y siguientes CC, manifestando con contundencia el Tribunal Supremo que «por incardinarse en la patria potestad derivando básicamente de la relación paterno filial (art. $110 \mathrm{CC}$ ), no ha de verse afectado por limitaciones propias del régimen legal de los alimentos entre parientes» (STS 5 de octubre de 1993, RJ 1993\7464); así como señalando el Constitucional «que mientras la obligación de alimentos entre parientes descansa en la situación de necesidad perentoria de los mismos o para subsistir y se le abona solo desde la fecha en que se interponga la demanda, los alimentos de los hijos, en la medida que tienen su origen en la filiación, artículo 39.3 de la Constitución española, ni precisan demanda alguna para que se origine el derecho a su percepción, ni la Ley prevé excepciones al deber constitucional de satisfacerlos» (STC 57/2005, de 14 de marzo). La Sentencia, dictada a consecuencia de las desigualdades de trato en cuanto al impuesto sobre la renta de las personas físicas - citada en el Auto de planteamiento y recogida en el voto particular - reitera las consideraciones de la previa STC 1/2001, en el sentido de resaltar el imperativo constitucional de que los padres presten asistencia de todo tipo a sus hijos menores, destacando que «tienen como único fundamento la relación paterno-filial, con independencia de que la filiación sea matrimonial o extramatrimonial, de que haya existido separación, nulidad o divorcio, e incluso de que los padres ostenten o no la patria potestad» ${ }^{17}$. No obstante, las trascendentes apreciaciones vertidas en las

nal Aranzadi Civil-Mercantil, n. ${ }^{\circ}$ 9/2015, parte Comentario (BIB 2014\4432). Vuelve a permitir la suspensión la reciente STS 2 de marzo de 2015 (RJ 2015\601), atendiendo en este caso al escenario de pobreza absoluta del progenitor deudor.

${ }^{17}$ Las diferencias entre los alimentos debidos a los hijos y la obligación legal de alimentos entre parientes se aborda con profundidad por MARTínEZ RODRÍGUEZ, N. (2002): La obligación legal de alimentos entre parientes, La Ley, Madrid, pp. 367 y ss., destacando la falta de similitud en cuanto a los presupuestos de exigibilidad, el diferente momento del nacimiento, la diversa amplitud de una y otra, la falta de reciprocidad, los modos de cumplimiento y las causas de extinción. 
resoluciones recogidas en el texto en nada le sirven al Constitucional como argumentos para poder haber admitido la cuestión planteada. Precisamente en el voto particular, formulado por el magistrado Xiol Ríos, se destaca el diverso fundamento de los alimentos a los hijos, que deriva exactamente del artículo $39 \mathrm{CE}$, citando los pronunciamientos de la STC 57/2005 y recogiendo sus diferencias con los parámetros que disciplinan la obligación legal de alimentos.

Sin duda, de entre las diferencias que pueden postularse entre una y otra obligación, nos interesa especialmente la circunstancia de que la obligación de alimentar a los hijos se origina, sin necesidad de mayores requisitos, por el nacimiento del hijo y no por la presencia del presupuesto de una situación de necesidad, sin que quepa en modo alguno apelar a la razón de la posible ignorancia de su incumbencia por parte del potencial alimentante, así como el hecho de que asiste a ambos progenitores y que debe acomodarse a las circunstancias de la familia. De lo expresado en la mencionada STS de 5 de octubre de 1993 claramente se deduce que la obligación que incumbe por imperativo del artículo 39 CE no exige de interposición de demandas para determinar su presencia, afirmación que, desde luego, casa mal con la limitación de exigibilidad que surge de la estricta aplicación del párrafo primero del artículo 148 CC.

Resulta claro, a mayor abundamiento, el contenido y extensión de la obligación, así como la opinión sustentada por el Tribunal de que el mandato constitucional no permite excepciones; no obstante, tal como se verá en el siguiente apartado, la aplicación de la limitación de exigibilidad prevista en el apartado primero del artículo 148 determina un acortamiento temporal de la obligación en detrimento del interés del hijo.

\section{EFECTOS DE LA APLICACIÓN DEL 148.1 DEL CÓDIGO CIVIL A LAS RECLAMACIONES ALIMENTARIAS}

Como ya se ha apuntado, existe una jurisprudencia consolidada en el sentido de negar efecto retroactivo a las obligaciones de alimentos, considerando claramente diferentes los conceptos de nacimiento de la obligación y exigibilidad de la misma ${ }^{18}$. Según esta doctrina — recogida

${ }^{18}$ La cuestión se analiza con detenimiento por Padial Albás, A. (1997): La obligación de alimentos entre parientes, Bosch, Barcelona, pp. 229 y ss. También, recogiendo las distintas posiciones doctrinales, REAL PÉREZ, A. (2000): «Comentario al artículo $148 \mathrm{CC}$, en Comentarios al Código Civil, T. II, vol. 2. ${ }^{\circ}$, Bosch, Barcelona, pp. 1454 y ss. y CAÑIZARES LASO, A. (2012): «Obligaciones familiares 
entre otras en la STS 8 de abril de 1995 (RJ 1995\2991), cuyos argumentos se reproducen sistemáticamente en otros procedimientos:

La reclamación judicial es la que concreta la prestación (cuantía o modo de pago), aunque exista con anterioridad el derecho a los alimentos y fuera exigible hasta llegar el recurrente a la mayoría de edad, efectivamente no los exigió», prosiguiendo que «no debe confundirse tiempo de nacimiento y tiempo de exigibilidad de los alimentos (...) Y planteada la exigencia de los alimentos ante los Tribunales, éstos por carecer aquellos de efecto retroactivo no pueden condenar a pagarlos sino desde la fecha que se interpuso la demanda; consecuencia todo ello de la regla clásica in praeteritum non vivitur y de estar concebidos los alimentos para subvenir a las necesidades presentes y futuras del alimentista y no para épocas ya pasadas en que el alimentista ha vivido sin los alimentos que ahora pide....

Las consideraciones reproducidas recogen el sentir de los tribunales respecto de negar la retroactividad de cualquier pretensión de alimentos aplicando el artículo $148 \mathrm{CC}$, si bien se ha fijado doctrina por el Tribunal Supremo en cuanto a los dos tiempos a los que se refiere la norma, procediendo a obligar al pago desde el momento de presentación de la demanda. Así la STS 14 de junio de 2011 (RJ 2011\4527) —citada por el Ministerio Fiscal, tal como menciona el Auto $^{19}-$, sienta la siguiente doctrina: «Debe aplicarse a la reclamación de alimentos por hijos menores de edad en situaciones de crisis del matrimonio o de pareja no casada la regla contenida en el artículo $148.1 \mathrm{CC}$, de modo que, en caso

básicas», en Derecho de familia, Civitas Thomson Reuters, Madrid, p. 140. En cuanto al aspecto específico de la irretroactividad, consultar CABEZUELO ARENAS, A. L. Y CASTILla BAREA, M. (2011): «La obligación de alimentos como obligación familiar básica», en Tratado de Derecho de la Familia, vol. I, Aranzadi, Cizur Menor, pp. 211 y ss.

${ }^{19}$ Lo que se discute en este procedimiento es si la condena debe establecerse desde la sentencia (como dice el precepto del Código) o, tal como se dispone en el fallo, desde el momento de interposición de la demanda, tiempo en que los alimentos se hacen exigibles, permitiendo la retroactividad al menos hasta el tiempo de la reclamación judicial, pero sin plantearse si pudiera extenderse a un momento anterior. Sobre la misma ver el detallado comentario de MARTínez RodRíGUEZ, N. (2012): «Alimentos para hijos menores cuando se reclaman en un proceso judicial por ruptura de relaciones entre sus progenitores. Aplicación del artículo 148.1 del Código Civil», Cuadernos Civitas de Jurisprudencia Civil, número 89, mayo-agosto 2012, pp. 157 y ss .

También abunda en el argumento la STS de 27 de noviembre de 2013 (RJ 2013 7855 ), en este caso en alimentos solicitados en el marco de un procedimiento de declaración de filiación no matrimonial. 
de reclamación judicial, dichos alimentos deben prestarse por el progenitor deudor desde el momento de la interposición de la demanda ${ }^{20}$. En realidad, aunque es cierto que la Sentencia del Supremo sienta esa doctrina, lo hace precisamente en interés del menor, al permitir adelantar la obligación no al momento de dictar la «sentencia», como había señalado la Audiencia, sino permitiendo retrotraerla al momento de presentación de la demanda, con lo que no sirven sus argumentos para el tema planteado en el Auto que es la retroacción a un momento anterior, sin tener en cuenta lo previsto por el artículo 148.1 CC.

Con el ánimo de atenuar el rigor de la aplicación del artículo 148.1 $\mathrm{CC}$, intenta la doctrina justificar el posible conocimiento del alimentante de la situación de necesidad como momento del inicio de la obligación - siguiendo con el cumplimiento de los presupuestos de la obligación-, atendiendo a otra posible lectura del precepto que permitiese su retroacción al tiempo de la reclamación extrajudicial ${ }^{21}$. El hecho de dirigirse un requerimiento al posible deudor, antes de entablar el procedimiento correspondiente, supondría la pérdida de valor del argumento de la potencial renuncia a los alimentos antes de su reclamación, barajado en ocasiones por los tribunales y la doctrina como justificativo de la falta de efecto retroactivo ${ }^{22}$, sirviendo para abundar en esta consideración la circunstancia de que el propio Código permitiría que aquel que voluntariamente prestó los alimentos sin estar obligado pudiera repetir después contra el deudor conforme a lo previsto en el artículo $1894 \mathrm{CC}^{23}$.

${ }^{20}$ Por el contrario, en los supuestos en los que la pretensión de alimentos forma parte de un procedimiento de modificación de medidas (conforme a los arts. 106 CC y 774.5 LEC), determina el Supremo la necesidad de distinguir entre la resolución que establezca por primera vez la prestación y las sucesivas que modifiquen su cuantía. En las primeras la fecha será la de presentación de la demanda, y en las siguientes la de la fecha de la resolución que modifique la cuantía. Así SSTS de 3 de octubre 2008 (RJ 2008\7123) y de 26 de marzo de 2014 (RJ 2014\2035), confirmando la doctrina anterior. Sobre esta última ver los comentarios de TenA PiAZUELo, I. (2015): La prestación de alimentos a los hijos tras la ruptura de pareja: pensiones, gastos, vivienda. Doctrina y jurisprudencia, Aranzadi, Cizur Menor, pp. 167 y ss.

${ }_{21}$ Por todos Padial AlBás, ob. cit., p. 234.

22 Así STS de 6 de noviembre de 1984 (RJ 1984\5443).

${ }^{23}$ Ver sobre esta cuestión SIERRA PÉreZ, I. (2001): «Comentario al artículo 148», en Código Civil comentado, Vol. I, Civitas-Thomson Reuters, Madrid, pp. 748-749. Formula críticas al precepto PALdiAl AlBÁs, A. (2011): «La obligación de alimentos», en Derecho de la Persona, Ravetllat Ballesté, I. (Coord.), Bosch, Barcelona, p. 152, por cuanto los alimentos a hijos menores son cargas familiares, así como por no reconocer el derecho a la retroacción a favor del cónyuge maltratado. 
Precisamente, el Código Civil de Cataluña atiende al posible momento de la reclamación extrajudicial como fecha de retroacción de los alimentos, estableciendo además para supuestos excepcionales, un plazo añadido de un año. Concretamente dispone el artículo 237-5, bajo el título «nacimiento del derecho»:

1. Se tiene derecho a los alimentos desde que se necesitan, pero no pueden solicitarse los anteriores a la fecha de la reclamación judicial o extrajudicial. 2. En el caso de los alimentos a los hijos menores, pueden solicitarse los anteriores a la reclamación judicial o extrajudicial, hasta un periodo máximo de un año, si la reclamación no se hizo por una causa imputable a la persona obligada a prestarlos ${ }^{24}$.

No obstante, volviendo al régimen del tratamiento de la cuestión en el ámbito del Código Civil, la aplicación de la norma expuesta a las reclamaciones de alimentos que incumben a los hijos menores no parece excepcionarse por los tribunales de la rigidez de la aplicación del artículo 148.1, lo que ha sido seriamente criticado por la doctrina. La posibilidad de mantener efectos retroactivos en el caso de los hijos menores se justificaría así en razones de responsabilidad ${ }^{25}$; en el propio contenido de la patria potestad ${ }^{26}$; en el artículo $39 \mathrm{CE}$, tantas veces mencionado; o, sin duda, en el principio de protección del menor, canon rector de la interpretación de cuantas normas atañen a los intereses de los menores $^{27}$, especialmente presente en la Convención de los Dere-

${ }^{24}$ Con una regulación del derecho de alimentos mucho más restrictiva en sus parámetros generales, en el Preámbulo que precede a la regulación del Libro II del CCCat., se alude a la excepcionalidad de la retroacción de alimentos, cuando la reclamación no se hizo por causa imputable al deudor, como norma de protección para los supuestos de malos tratos, si bien, en sentir de la doctrina podría extenderse a cualquier otro caso en que se apreciase un comportamiento imputable al deudor. Por todos RUDA GonZÁlez, A. (2014): «Comentari del artículo 237-4», en Comentari al llibre segon del Codi Civil de Catalunya, Atelier, Barcelona, p. 998.

${ }^{25}$ Lo justifica de esta manera BARBER CÁRCAMO. R. (2011): «Comentario al artículo 110», en Código Civil comentado, Vol. I, Civitas-Thomson Reuters, Madrid, p. 591.

${ }^{26}$ Así Cuena Casas, M. (2013): en «Comentario al artículo 148», en Comentarios al Código Civil, T.I, Tirant lo Blanch, Valencia, pp. 1497 y 1498, considerándolo un deber indelegable y afirmando textualmente: «creo que cuando se trata de menores, aplicar la regla in praeteritum non vivitur me parece un auténtico exceso que desnaturaliza y confunde las obligaciones dimanantes de la patria potestad con la genuina obligación alimentos».

${ }^{27}$ La reciente reforma de la LO 1/1996, de 15 de enero, de Protección Jurídica del Menor, por obra de la LO 8/2015, de 22 de julio, destaca en su Preámbulo la consideración del interés superior del menor en los siguientes términos: «Este concepto se 
chos del Niño, adoptada por la Asamblea General de las Naciones Unidas el 20 de noviembre de 1989 y ratificada por España, en cuyo artículo 3 se dispone la necesidad de que los tribunales atiendan a ese interés, que aconsejaría una hermenéutica del artículo 148 del CC más acorde con la protección de los valores que protege la Convención sin privar al menor del derecho a ser alimentado durante su minoría de edad ${ }^{28}$.

El propio Tribunal Constitucional se ha hecho eco en sus resoluciones del mencionado principio del interés superior del menor, destacando y admitiendo su trascendencia, afirmando, por ejemplo, que el artículo 39 CE es una concreción del mismo, en la STC 138/2014, principio que se define como rector e inspirador de todas las actuaciones de los poderes públicos, concretándose especialmente, según STC 217/2014, en los procesos matrimoniales y de familia. Ahora bien, como se verá más adelante, no parece apoyarse en su valor el fallo del Auto, no considerando conculcado tal interés, en franca contradicción con otras apreciaciones sobre su valor dictadas por el propio Constitucional. Resulta bastante evidente que cuanto mayor sea el periodo de retroacción de los efectos de la obligación de alimentos, mayor será el interés del

define desde un contenido triple. Por una parte, es un derecho sustantivo en el sentido de que el menor tiene derecho a que, cuando se adopte una medida que le concierna, sus mejores intereses hayan sido evaluados y, en el caso de que haya otros intereses en presencia, se hayan ponderado a la hora de llegar a una solución. Por otra, es un principio general de carácter interpretativo, de manera que si una disposición jurídica puede ser interpretada en más de una forma se debe optar por la interpretación que mejor responda a los intereses del menor. Pero además, en último lugar, este principio es una norma de procedimiento. En estas tres dimensiones, el interés superior del menor tiene una misma finalidad: asegurar el respeto completo y efectivo de todos los derechos del menor, así como su desarrollo integral».

${ }^{28}$ Dispone concretamente el artículo 3.1. de la Convención: «En todas las medidas concernientes a los niños que tomen las instituciones públicas o privadas de bienestar social, los tribunales, las autoridades administrativas o los órganos legislativos, una consideración primordial a que se atenderá será el interés superior del niño». La Convención se menciona varias veces a lo largo del Auto objeto de este comentario, no siendo especialmente tenida en cuenta en los fundamentos jurídicos del fallo, aunque sí en las consideraciones del voto particular, en el que, textualmente, se recoge el contenido del artículo 18.1: «Los Estados Partes pondrán el máximo empeño en garantizar el reconocimiento del principio de que ambos padres tienen obligaciones comunes en lo que respecta a la crianza y el desarrollo del niño. Incumbirá a los padres o, en su caso, a los representantes legales la responsabilidad primordial de la crianza y el desarrollo del niño. Su preocupación fundamental será el interés superior del niño».

Sobre el mencionado interés, ver, recientemente, Guilarte Martín-CALERo, C. (2014): La concreción del interés del menor en la jurisprudencia del Tribunal Supre$m o$, Tirant lo Blanch, Valencia, pp. 13 y ss. 
menor satisfecho, y que la limitación temporal que surge de la interpretación que se lleva a cabo del párrafo primero del artículo 148 CC claramente conculca ese beneficio.

\section{MOTIVOS DE INADMISIÓN A TRÁMITE DEL RECURSO}

Amparándose en el contenido del artículo 37.1 de la Ley Orgánica del Tribunal Constitucional, decide el Auto la inadmisión del recurso por considerar notoriamente infundada la cuestión suscitada, si bien entiende que no existe objeción alguna en cuanto a la presencia de condiciones procesales. En los apartados siguientes analizaremos las consideraciones generales y los motivos específicos que determinan la apreciación de falta de viabilidad, pudiendo observarse que los argumentos esgrimidos y recogidos en los fundamentos no resuelven la cuestión adentrándose en la profundidad de matices que requeriría su adecuado tratamiento, sino que se procede a resolver de una forma rápida y tajante. Creo, por el contrario, que la materia y el planteamiento revisten la solidez suficiente como para haber aconsejado la admisión a trámite de la cuestión.

\section{Cuestión notoriamente infundada}

El hecho de considerar la cuestión notoriamente infundada, en sentir del propio Tribunal, «no implica un juicio peyorativo sobre la duda constitucional», aunque sí permite un examen preliminar de la viabilidad de la cuestión. Atendiendo a los argumentos que más adelante examinaremos, se considera suficiente con la Audiencia del Fiscal General del Estado para dirimir la cuestión, prescindiendo, como hubiera sucedido si se hubiera superado el férreo control, de las alegaciones de las partes en el procedimiento, tal como permite el artículo 37. 2 LOTC, desde la reforma operada por Ley $6 / 2007^{29}$.

Se trata esta de una de las objeciones del voto particular formulado por el magistrado Xiol Ríos, entendiendo que la ampliación que viene haciendo el Tribunal de la cuestión «notoriamente infundada» no permite

29 Alegaciones que, antes de la reforma operada en el 2007, se limitaban a lo permitido en el artículo 35.2 LOTC, dentro del proceso en el que se planteaba la cuestión de inconstitucionalidad, pero no antes. Ver Medina Guerrero, M., (2000), en Jurisdicción y procesos constitucionales, 2. ${ }^{\mathrm{a}}$ edic., McGraw Hill, p. 63. 
contar con el parecer de las partes, posibilitado mediante una reforma plausible al dar entrada en el proceso de declaración de inconstitucionalidad a opiniones que pueden considerarse de especial trascendencia. Textualmente se dice en el voto particular que «la nueva regulación viene a poner de manifiesto que la cuestión de inconstitucionalidad también se está reforzando como instrumento de la ciudadanía en la labor de depuración de la constitucionalidad de las normas con rango de ley, que antes estaba limitada a la posibilidad de instar el planteamiento de la cuestión de inconstitucionalidad dentro del procedimiento judicial (art. 35.1 CE)». Sin duda alguna, esa posibilidad queda truncada con la inadmisión a trámite que, siguiendo con el contenido del voto particular, debería llevar al Tribunal a reconsiderar la generosa aplicación que se viene haciendo de la cuestión notoriamente infundada «y encontrar un equilibrio entre las razones pragmáticas que han alimentado históricamente su expansión y el actual contexto, en que también resultan relevantes (i) el derecho a que se tomen en consideración las opiniones de quienes pueden legalmente personarse y hacer alegaciones en este procedimiento, entre otros posibles aspectos, sobre la posible vulneración de derechos fundamentales; y (ii) la posibilidad de que el Tribunal tome en consideración esas alegaciones en una decisión que afecte al fondo de la cuestión».

La circunstancia de no admitir a trámite la cuestión, haciendo abstracción del posible juicio de constitucionalidad del precepto en cuestión, no permite contar con unas alegaciones y razonamientos detallados de las diferentes cuestiones que se entremezclan en la aplicación de las diferentes normas presentes, siendo una ocasión no aprovechada para llevar a cabo un análisis más profundo de una materia en la que, sin duda, parecen confluir líneas de interpretación poco acordes con lo preceptuado en la Constitución, planteada con claridad por el Juzgado que propone la cuestión ${ }^{30}$.

El Tribunal se apoya en el contenido de Autos previos relativos a la cuestión notoriamente infundada, como el ATC 32/2009 de 27 de enero, en el que se sienta la doctrina, tantas veces reiterada, de que «encierra un cierto grado de indefinición que se traduce procesalmente en otorgar a este Tribunal un margen de apreciación a la hora de controlar la solidez de la fundamentación de las cuestiones de inconstitucionalidad (...) sin que ello signifique, necesariamente, que carezca de forma total y absoluta de fundamentación o que esta sea arbitraria, pudiendo resultar conveniente en tales casos resolver la cuestión en la primera fase procesal, máxime su admisión pudiera provocar efectos no desea-

${ }^{30}$ Así lo considera BerCOVITZ, ob. cit., p. 2. 
bles, como la paralización de múltiples procesos en los que resulte aplicable la norma cuestionada». Por lo que se verá seguidamente, no creo que pueda afirmarse que falta solidez en la fundamentación de la cuestión, habiendo sido conveniente salvar el trámite de la inviabilidad con el fin de contar con mayores argumentos que pudieran ayudar a dirimir la materia sin prejuzgar, necesariamente, sobre el juicio definitivo del Tribunal ${ }^{31}$.

\section{Análisis de la viabilidad de la duda de constitucionalidad}

Como ya he apuntado, considera el Tribunal, acotando la cuestión, que no se trata de la compatibilidad entre el artículo 39 de la CE y el 148.1 in fine del CC, sino «respecto de la limitación temporal de la exigibilidad», entendiendo que el auto de planteamiento adolece de falta de argumentos que conecten ambas cuestiones. Debo reconocer que cuesta seguir la línea del Tribunal, por cuanto prosigue diciendo que «dado que hay que evaluar la respuesta del legislador en cuanto no excluye de la norma el supuesto de alimentos a hijos menores, es preciso determinar si esta solución responde a los intereses en presencia, con prevalencia del interés superior del menor; si bien, teniendo también en cuenta el valor constitucional relevante de la protección integral de los hijos, sin perder de vista, al mismo tiempo, la seguridad jurídica» ${ }^{32}$.

${ }^{31}$ Uno de los Autos citados para abundar en la apreciación de la falta de solidez, el ATC 177/2014, de 24 de junio, se refiere a la comparación de jornadas laborales de dos colectivos de trabajadores y la posible infracción del principio de igualdad; el otro, ATC 2008/71, de 26 de febrero, tras recoger la doctrina formulada en el texto, se centra en la inadmisión de la cuestión sobre una tasa que grava las máquinas recreativas de juego por vulneración de los principios de igualdad en materia tributaria y de capacidad económica, así como el principio de interdicción de la confiscatoriedad, ni tampoco los derechos a la propiedad privada y a la libertad de empresa en el marco de la economía de mercado. La dimensión de las cuestiones objeto de debate y los argumentos esgrimidos a la hora de plantear las cuestiones no creo que sean comparables a la que ocupa la atención del Auto objeto de comentario en cuanto a la solidez de las razones del planteamiento.

32 Para ello apela a la cita de las SSTC 273/2005 y 138/2005, cuyo paralelismo no encuentro muy fundamentado.

En la STC 138/2005 se ocupa el Tribunal de la inconstitucionalidad del párrafo 1. ${ }^{\circ}$ del artículo 136 CC, aludiéndose a la seguridad jurídica en las relaciones familiares y a la estabilidad del estado civil de las personas que aconsejan el señalamiento de plazos en el ejercicio de las acciones de filiación, lo que no impide que se declare en la Sentencia la inconstitucionalidad del precepto que determinaba que el plazo comenzaría a correr desde el nacimiento del hijo o desde que el padre conociera el nacimiento, per- 
La manera en la que aborda el Tribunal la garantía del interés superior del menor, como esencial a la hora de valorar la razonabilidad y proporcionalidad de la norma enjuiciada, avanza seguidamente por unos derroteros extraños, en los que poco, o nada, se tiene en cuenta la relación entre los preceptos cuyo análisis se requiere ${ }^{33}$. No entra el Auto en el hecho de analizar que el tenor literal del artículo 148.1 in fine del CC y su aplicación por los Tribunales a las reclamaciones de los hijos menores implica una clara infracción de la extensión de la obligación de alimentar a los hijos que, por imperativo constitucional, debe extenderse a toda la minoría de edad. El resultado de la aplicación por los tribunales ordinarios, concretamente por el Supremo, de esa limitación temporal deja al menor, sin duda posible al respecto, en una clara situación de perjuicio, al perder unos alimentos, no ajustados a los paráme-

mitiéndose las acciones de impugnación entabladas por padres que, en un momento posterior y con una mayor conculcación de la seguridad jurídica, lleguen a conocer que el hijo no es suyo. Es decir, la anulación del inciso correspondiente permite un ejercicio más tardío y más amplio de la acción de impugnación de la filiación.

En cuanto a la otra resolución citada, la STC 273/2005, tampoco encuentro una evidente relación en el sentido de considerar inviable la cuestión, sino más bien al contrario. En este caso se enjuicia, nuevamente, el complejo panorama de las acciones de filiación y el derecho del hijo a que se determine su verdadera filiación, por lo que se declara inconstitucional el párrafo $1 .^{\circ}$ del artículo $133 \mathrm{CE}$ con el fin de no tratar de modo diverso a la reclamación de la filiación matrimonial respecto de la no matrimonial. Precisamente se apoya el fallo en las consideraciones de una Sentencia previa, la STC 7/1994, en la que expresamente se mantiene que «la interpretación de las leyes que rigen esta materia debe realizarse en el sentido que mejor procure el cumplimiento por los padres de sus deberes respecto a sus hijos menores».

Tanto en un supuesto como en el otro creo que se plantea una interpretación de la seguridad jurídica y del contenido de las normas en el sentido de beneficiar los derechos de los menores, manteniéndose posturas de mayor flexibilidad que el caso del Auto objeto de comentario y que, incluso, podrían haber servido como apoyo precisamente en el sentido contrario, supeditando los derechos de los hijos menores, en este caso a ser alimentados, a los rígidos parámetros de la seguridad jurídica. Ambos textos normativos han sido reformados en el sentido expuesto por la Ley 26/2015, de 28 de julio, de modificación del sistema de protección de la infancia y adolescencia.

${ }^{33}$ El propio Tribunal, en STC 138/2014, afirma contundentemente la trascendencia que presenta el principio del interés superior del menor para juzgar sobre el concepto de la «razonabilidad», declarando que «el canon de razonabilidad constitucional deviene más exigente por cuanto que se encuentran implicados valores y principios de indudable relevancia constitucional, al invocarse por el demandante de amparo el principio del interés superior del menor que tiene su proyección en el artículo 39 CE y que se define como rector e inspirador de todas las actuaciones de los poderes públicos, tanto administrativos como judiciales (SSTC 141/2000, de 21 de mayo, FJ 5 y 127/2013, de 3 de junio, FJ 6, entre otras)». 
tros de necesidad, sino acomodados a las circunstancias de la familia, que ya no serán satisfechos y que, a mayor abundamiento, se le deben por partida doble, abstracción hecha de que se hayan satisfecho o no sus mínimas exigencias vitales.

No aborda la resolución valoración alguna sobre esa contingencia, que es precisamente la que constituye el objeto de la cuestión de inconstitucionalidad, claramente planteada por el órgano recurrente. No creo que pueda negarse que la relación de ambos preceptos implica un «incumplimiento real» del mandato constitucional, pues se acorta el periodo de la obligación de alimentar al hijo durante todo el tiempo anterior a la interposición de la demanda; la aludida conexión entre ambas reglas es obvia, como también lo es que el hecho de que el menor no reciba esos alimentos atrasados, por efecto de la negación de efectos retroactivos, perjudica su interés, pues ya no los percibirá nunca, con independencia, insisto, de que sus necesidades vitales hayan quedado satisfechas, pues la obligación incumbe a ambos progenitores en proporción a las circunstancias de la familia. El invocado interés del menor y la cita de los preceptos correspondientes de la Convención sobre los derechos del niño aconsejaría una interpretación de la norma más favorable al cumplimiento del mandato constitucional que es, precisamente, el resultado al que nos conducen las apreciaciones del Auto $^{34}$.

Lo que hace el Tribunal, por el contrario, es poner atención, a la hora de examinar la viabilidad de la cuestión, en qué sucedería si se reconociera efecto retroactivo a la obligación, pero no desde el punto de vista de la situación del menor, sino atendiendo al resarcimiento de aquel progenitor que cumplió su obligación, poniendo en relación la norma con los intereses de los padres deudores (uno cumplidor y otro incumplidor) como veremos seguidamente. En ningún momento se plantea que el destinatario de esa prestación frustrada pudiera ser el propio hijo, y no el progenitor que sí atendió sus obligaciones, extremo este que no forma parte del planteamiento de la cuestión de inconstitucionalidad. Por el contrario, se procede a relacionar cómo podría afectar la retroactividad al interés del menor, considerando que no es algo inmediato, así como que la retroacción no se orientaría a la asistencia del

${ }^{34}$ El propio Tribunal alude al principio del interés superior del niño como rector de las medidas que puedan adoptar los tribunales, con cita de pronunciamientos al respecto, como las SSTC 124/2002 y 47/2009. También se refieren al mismo, destacando su importancia y trascendencia, las mencionadas ya SSTC 33/2006, STC 217/2009 o 138/2014. 
menor, extremo sobre el que creo que existen serias dudas, porque en mi opinión la satisfacción del interés del menor, desde luego, quedaría garantizada por el hecho del cumplimiento de la obligación previamente incumplida por uno de sus progenitores.

De modo completamente diferente, lo que hace el Auto es partir del equilibrio con otros intereses para juzgar sobre la superación del juicio de ponderación, siendo los del progenitor, custodio o no, los que prevalecen en la valoración del Tribunal, así como una apreciación particular sobre los efectos de la posible retroactividad respecto del principio de seguridad jurídica.

En primer lugar considera la resolución que la retroactividad «favorecería el resarcimiento del progenitor que cumplió su obligación ex artículo 154.1 del Código Civil», considerando seguidamente que no se orientarían a la asistencia del menor «pues el menor ya fue asistido y sus necesidades de todo orden fueron cubiertas. Y si no lo fueron, los alimentos reclamados retroactivamente no servirían para cubrirlas ya». El mimetismo con los parámetros que disciplinan la regulación de la obligación legal de alimentos entre parientes es extraordinario. Es exactamente la aplicación de la regla in praeteritum non vivitur lo que lleva a cabo el Auto en su planteamiento, siguiendo a rajatabla la interpretación propia de aquella obligación que es, precisamente, la que se trata de eludir en la cuestión de inconstitucionalidad, planteando el Juzgado al Tribunal la posibilidad de fijar una línea hermenéutica que posibilite el cumplimiento del mandato constitucional y de las reglas del Código relativas a los alimentos de los hijos menores.

La argumentación, en términos del voto particular, no resulta «convincente», al contravenir la consideración propia de la obligación de alimentar a los hijos menores y las diferencias que la delimitan frente a la prestación legal de alimentos entre parientes. Siguiendo las expuestas afirmaciones doctrinales sobre la materia se van apuntando por el magistrado discordante la circunstancia de que los alimentos deben proporcionarse en atención a la posición del deudor, así como que el hecho de que se hayan prestado por uno de los progenitores «no impide afirmar que la obligación constitucional de asistencia existía ya con carácter previo a la presentación de la demanda y permanece vigente con independencia de cualquier otra consideración». Niega el voto particular - entiendo que con sobrados argumentos, coincidiendo absolutamente con sus afirmaciones - , que no exista conexión entre la irretroactividad y la obligación de prestar asistencia a los hijos menores. 
Prosiguiendo en sus consideraciones, tras recalcar contundentemente que al menor le incumbe el derecho a recibir alimentos de ambos progenitores, por lo que al recibirlos de uno solo de ellos se habrá conculcado la regla constitucional, no entiende Xiol «cómo se sostiene en la opinión sustentada por la mayoría, que el incumplimiento del impago de alimentos por uno de los progenitores se traduzca simplemente en una deuda a favor del progenitor que hizo frente a dicha obligación». Con acierto entiende que el titular del derecho es el hijo, con independencia de que el otro progenitor actúe como su representante legal, con lo que, en mi opinión, de reconsiderarse los efectos retroactivos del precepto el beneficiado sería claramente el menor y no el progenitor.

Es decir, lo que se pretende con el planteamiento de la cuestión de constitucionalidad no es afirmar el derecho del reintegro del progenitor que cumplió - que de tenerse en cuenta en nada beneficiaría al menor que vería satisfecha solo parte de la prestación a que tiene derecho, continuando la situación de vulneración de su derecho - lo que se persigue, por el contrario, es que reciba el menor la totalidad de la asistencia que le corresponde como cumplimiento de los deberes inherentes a la filiación.

En segundo lugar se plantea el Auto la superación del juicio de ponderación con otros intereses, concretamente los de los progenitores. En este sentido considera el Tribunal que «(r)especto al progenitor custodio la norma no es excluyente, pues nada le impide formular demanda en reclamación de alimentos tan pronto como nace la obligación. Respecto al progenitor no custodio, tampoco es excluyente pues puede cumplir voluntariamente su obligación desde que esta nace y, en los supuestos de cumplimiento forzoso, una delimitación temporal de la exigibilidad de los alimentos parece proporcionada para evitar una situación de pendencia, difícilmente compatible con el principio de seguridad jurídica (art. 9. $3 \mathrm{CE}$ )».

Con todo respeto disiento nuevamente de las afirmaciones contenidas en el Auto que vuelven a reproducir las características propias de la obligación legal de alimentos entre parientes pese a haber constatado las diferencias entre ambas. Desde luego que la reclamación, dentro de la órbita de aplicación del artículo $148,1{ }^{\circ} \mathrm{CC}$ solo judicial, puede plantearse antes, no hay duda posible al respecto, pero se trata de un argumento propio del establecimiento de una obligación cuya existencia puede desconocerse y, precisamente por ello, se acude a los tribunales con el fin de que determinen su reconocimiento, mientras que la obligación de dar asistencia a los hijos menores por imperativo del artículo 39 
CE existe desde que el menor nace, debiendo cumplirse y hacerse efectiva desde ese momento ${ }^{35}$. Hacer depender la existencia de esa obligación de la presentación de una demanda implica dejarla sin efectividad, por no mencionar que no puede imponerse una especial diligencia al progenitor cumplidor en cuanto a la rápida presentación de una reclamación judicial para que el hijo menor vea satisfecho su derecho a ser alimentado por ambos progenitores. Nuevamente la situación conduce claramente hacia el planteamiento de la cuestión de inconstitucionalidad que no es otro que observar la relación entre las normas para constatar que el artículo 148, párrafo primero, del CC determina un acortamiento de la obligación.

Llama igualmente la atención que, textualmente, se refiera el Auto a la circunstancia de que el progenitor no custodio «puede» cumplir voluntariamente con su obligación. Hubiera sido preferible el empleo de una terminología más acorde con el cumplimiento de una obligación de tales características, destacando sin duda posible al respecto el carácter imperativo del cumplimiento de la prestación, tantas veces afirmado por doctrina y jurisprudencia. El artículo $39 \mathrm{CE}$ utiliza la expresión deben, lo que contrasta con esa cierta permisividad que se trasluce de la resolución al trasladar una argumentación propia de la obligación legal de alimentos entre parientes en la que, exactamente, la hipótesis del cumplimiento voluntario previo a la reclamación judicial elimina la posibilidad de repetir. Entiendo que el argumento no debería haberse traído a colación por las especiales notas que acompañan el contenido de la filiación y de la patria potestad.

El voto particular reflexiona igualmente sobre esta cuestión manteniendo que «la obligación constitucional de prestación de asistencia de ambos progenitores al niño aparece en nuestro ordenamiento formulada de una manera incondicionada, lo que responde a la lógica de que se inspira en el principio del interés superior del menor [...]». Resulta mucho más ajustado propugnar la incondicionalidad del deber que corresponde a los padres, separando claramente el contenido de esta obligación de alimentos respecto de otras.

${ }^{35}$ Es más, incluso en el ámbito de la obligación legal de alimentos entre parientes la doctrina que más ha estudiado la cuestión considera que tal interpretación por parte de los tribunales favorece poco el cumplimiento voluntario, fomentando la pasividad del deudor, teniendo en cuenta, por otra parte, que el retraso en la interposición de la demanda puede obedecer a multitud de causas, incluso provocadas por el propio alimentante. Así se expresa MARTínEZ RodríGUEZ, ob. cit., pp. 280 y ss, abogando por la necesidad de una reforma del Código. 


\section{V. ¿POSIBILIDAD DE DICTAR UNA SENTENCIA INTERPRETATIVA?}

Cuando centra el Tribunal los términos del debate, con el ánimo de examinar la posible contradicción entre el artículo 148.1, final CC y el artículo 39 CE, considera el Auto que el juicio debe referirse exclusivamente a la limitación temporal de la exigibilidad de los alimentos y su aplicabilidad a los hijos menores de edad «en la medida en que este supuesto no se excepciona en la norma».

Atendiendo a lo que solicita el Juzgado que propone la cuestión, en el sentido de requerirse para este supuesto una solución especial y no la general, partiendo de las peculiaridades de estos alimentos y su carácter de obligación constitucional, niega el Tribunal el argumento sin entrar en una consideración más reflexiva del mismo, creo que, con cierta precipitación $^{36}$. Cercenando de este modo la posibilidad de una sentencia interpretativa textualmente se dice:

En puridad, no puede decirse que estemos ante dos posibles interpretaciones que cabría atribuir al precepto legal (inclusión o exclusión de los alimentos a hijos menores), pues el contenido del mismo y su vocación general son claros. Además, ha de recordarse que los preceptos relativos a los alimentos entre parientes, entre ellos el artículo 148 del Código Civil, se aplican en los supuestos de alimentos que dimanan de la patria potestad (art. 154.1 del Código Civil) con carácter supletorio, de conformidad con el artículo 153 del Código Civil, también de significado unívoco.

El argumento, en mi opinión, no resulta excesivamente esclarecedor, porque no se está poniendo en entredicho la posible vocación general del precep-

${ }^{36}$ Parece compartir el pronunciamiento el parecer del Fiscal General del Estado que propone la inadmisión de la cuestión como notoriamente infundada, «pues, lo que plantea el órgano proponente no es una duda de constitucionalidad sobre una norma sino sobre la jurisprudencia acogida por el Tribunal Supremo, es decir, no se pide al Tribunal Constitucional que depure el ordenamiento sino que determine cuál de las soluciones debe ser aplicable», finalidad que, según el fiscal no es la de la cuestión de inconstitucionalidad, negando la posibilidad de una sentencia interpretativa. En apoyo de su postura, invoca el fiscal el ATC59/2013, de 26 de febrero, en cuyo Fundamento Tercero se afirma que la finalidad de la cuestión de inconstitucionalidad «no estriba en resolver controversias interpretativas sobre la legalidad o dudas sobre el alcance de determinado precepto legal, para lo cual el ordenamiento dispone de otros cauces», rechazando tajantemente la posible existencia de sentencias interpretativas al no admitir que el Constitucional pueda despejar dudas sobre cuál de las posibles interpretaciones sea más ajustada a la Constitución. 
to, ni su posible carácter supletorio, sino la consideración de una declaración de excepcionalidad de aplicación para un supuesto concreto. La regla, por otra parte preconstitucional y propia de otros alimentos, sin duda está llamada a cumplir una función general, por todas las razones que se han examinado hasta el momento, finalidad que quedaría en entredicho con una sentencia que se limitase a declarar la inconstitucionalidad de la misma. Sin duda alguna se estaría ante uno de esos supuestos de horror vacui ${ }^{37}$ que acarrearía la declaración de la nulidad sin más del precepto, ocasionándose muchos más problemas en su aplicación y consideración, pero que, precisamente por ello, podrían aconsejar la búsqueda en vía interpretativa de una concordancia entre lo previsto en el artículo 148.1 del CC y el artículo $39 \mathrm{CE}^{38}$.

Precisamente por tales circunstancias, el recurso a la compleja y controvertida categoría de las sentencias interpretativas permitiría que el Tribunal, habiendo debido admitir la cuestión a trámite, se manifestase sobre la posible significación del precepto ${ }^{39}$, a la vista del contenido del artículo $39 \mathrm{CE}$, ofreciendo «una interpretación en consonancia con la Constitución que permite mantener su validez ${ }^{40}$, o excluyendo la constitucionalidad de alguna de las interpretaciones posibles ${ }^{41}$.

37 Siguiendo las palabras de GARCía DE ENTERRÍA, E. (1988): La constitución como norma y el Tribunal Constitucional, Civitas, Madrid, p. 96.

${ }^{38}$ Ver sobre la materia, JIMÉNEZ CAMPO, J. (1977): «Qué hacer con la ley inconstitucional», en La sentencia sobre la constitucionalidad de la ley, Cuadernos y debates, n. ${ }^{\circ}$ 66, Tribunal Constitucional, Centro de Estudios Constitucionales, Madrid,pp. 47 y ss.; DíAz Revorio, F. (2000): «Interpretación constitucional de la ley y sentencias interpretativas», Repertorio Aranzadi del Tribunal Constitucional, n. ${ }^{\circ} 2 / 2000$, parte Estudio, BIB 2000\6; OrTIZ HerRERA, S. (1997): «Articulación del Tribunal Constitucional y del poder judicial en la labor interpretativa de la Constitución. Especial referencia a las sentencias interpretativas del Tribunal Constitucional», Boletín de la Facultad de Derecho, n. ${ }^{\circ}$ 12, Universidad Nacional de Educación a Distancia; y, especialmente, ZAGREBELSKY, G. (1988): La giustizia costituzionale, Il Mulino, Bolonia pp. 292 y ss.

${ }^{39}$ Lo considera así también BERCOVITZ, ob. cit., p. 1.

${ }^{40}$ Son palabras textuales de ENTERRía, ob. cit., p. 103, quien continúa su argumentación en los términos siguientes: «es el problema de las llamadas "sentencias interpretativas" del Tribunal Constitucional y en particular en Italia "sentence interpretative di rigetto". Estas sentencias no tendrán valor erga omnes, efecto que el artículo 164 limita a las que declaren la inconstitucionalidad, y estas la rechazan, pero como tal doctrina jurisprudencial, y no como Ley o efecto general, prevalecerá sobre la del Tribunal Supremo en cuanto haga referencia a la compatibilidad constitucional de la Ley interpretada, esto es, en cuanto la interpretación del Tribunal Supremo suponga una colisión con la Constitución - no, por supuesto, en otro caso-».

${ }^{41}$ Son muchas las clases de sentencias interpretativas que puede dictar el Tribunal, tanto desestimatorias como estimatorias, pudiendo a su vez revestir diversas modalidades, lo que repercute en el modo de resolver la cuestión y en los posibles efectos de la resolución. Una clasificación detallada de las mismas en DíAz REVORIO, ob. cit., 
En apoyo de esa posible búsqueda de una línea interpretativa adecuada al interés superior del menor vendría de la aplicación de lo dispuesto en la, mencionada, Convención de los Derechos del Niño, plasmada y recogida en el vigente texto de la LO 1/1996, de 15 de enero, de Protección Jurídica del Menor, reformada por la LO 8/2015, de 22 de julio, en cuyo Preámbulo se incide en destacar la función hermenéutica de este principio en los siguientes términos: «Por otra, es un principio general de carácter interpretativo, de manera que si una disposición jurídica puede ser interpretada en más de una forma se debe optar por la interpretación que mejor responda a los intereses del menor». Las recientes palabras de la exposición de motivos reflejan perfectamente la influencia que se viene predicando de la necesidad de proteger el interés superior del menor.

La admisibilidad de la resolución de las cuestiones de inconstitucionalidad mediante el recurso a una sentencia interpretativa ha sido reconocida en nuestro ordenamiento por el propio Tribunal, definiéndolas pronto en la STC 5/1981, como «aquellas que rechazan una demanda de inconstitucionalidad o, lo que es lo mismo, declaran la constitucionalidad de un precepto impugnado en la medida en que se interprete en el sentido que el Tribunal Constitucional considera como adecuado a la Constitución, o no se interprete en el sentido (o sentidos) que considera inadecuados».

Tal como expresa la doctrina la posibilidad de dictar tales sentencias interpretativas se ha visto rodeada de notables prevenciones ${ }^{42}$, no pudiendo, en palabras del Tribunal, ser objeto de pretensión por los recurrentes, adoptándose diversas modalidades, y admitiéndose incluso que no siempre tengan reflejo en el fallo. Dentro de las diversas categorías de sentencias de esta índole podría apuntarse la conveniencia de reflexionar en este supuesto en particular sobre las dirigidas a reducir el ámbito de aplicación de un precepto (sentencias reductoras) ${ }^{43}$, o aquellas que consideran inconstitucional una norma al no incluir el contenido que debería (sentencias aditivas $)^{44}$. En el primer caso la regla, adecuadamente interpretada, dejaría de ser de aplicación a alguno de los

pp. 3 y ss. ZAGREBELSKY, ob. cit., p. 292, habla de sentencias interpretativas de rigetto y de accoglimento, si bien el propio autor reconoce que son dos caras de la misma moneda, que pueden ser fácilmente intercambiables.

42 Así Medina GutiÉRREZ, ob. cit., pp. 72 y 73.

${ }^{43}$ Sobre las mismas ver JIMÉNEZ CAMPO, ob. cit., p. 50, definiéndolas como aquellas que «eluden la declaración de nulidad del precepto - inconstitucional en uno de sus entendimientos - por vía de la reducción de su ámbito de aplicación». También DíEZ REVORIO, ob. cit., pp. 8 y ss.

44 Ver Díez Revorio, ob. cit., p. 19. 
supuestos comprendidos en abstracto en su enunciado, esto es, a lo que interesa ahora, el párrafo enjuiciado del artículo 148.1 CC no se extendería a la obligación de alimentar a los hijos menores. En el segundo podría considerarse inconstitucional el precepto en no prever o recoger la excepcionalidad de la obligación que nos ocupa.

Sin duda el Tribunal Supremo podría haberlo venido declarando así, pues no existe regla en el Código que determine que los alimentos a los hijos tengan que subsumirse en los presupuestos rígidos del artículo $148,1 .^{\circ} \mathrm{CC}$, pero no lo ha considerado de esta manera en sus reiterados pronunciamientos. Ahora bien, lo que parece una verdad incontrovertible es que el Constitucional es el intérprete supremo de las normas y, como tal, haciendo uso de las posibilidades que le asisten ante el tratamiento de las cuestiones de inconstitucionalidad, podría proceder a la correcta hermenéutica del precepto, acudiendo a la categoría de las sentencias interpretativas.

Por todo ello, sin prejuzgar sobre esta difícil cuestión, hubiera sido conveniente la admisión a trámite del recurso para que, al menos, pudiera haberse reflexionado sobre la procedencia de alguna de estas posibles soluciones para resolver el supuesto enjuiciado.

Concluyendo con las palabras recogidas en el voto particular, «a mi juicio era inexcusable, en la mejor tradición de la jurisprudencia sobre protección de los derechos constitucionales, un análisis más profundo del juicio de proporcionalidad, en que no solo se constatara que esta limitación temporal persigue el fin de evitar situaciones de inseguridad jurídica y que este es legítimo, sino además, que la restricción operada es necesaria, que es idónea para la consecución de ese fin y que no existen otros medios menos incisivos o restrictivos de los derechos del niño para su consecución».

\section{OTROS POSIBLES EFECTOS DERIVADOS DE LA FALTA DE PRESTACIÓN DE ALIMENTOS A LOS HIJOS MENORES}

En las resoluciones dictadas sobre reclamaciones de alimentos y en los tratamientos doctrinales sobre el particular, se suele hacer mención a los posibles recursos contra el alimentante por parte de la persona que hubiera venido prestando alimentos como posible atenuación a la falta de efectos retroactivos de la reclamación, en el sentido de resarcir a quien indebidamente ha satisfecho la prestación que no le correspondía.

El artículo 1894 del CC dispone al respecto: «Cuando, sin conocimiento del obligado a prestar alimentos, los diese un extraño, este 
tendrá derecho a reclamarlos de aquel, a no constar que los dio por oficio de piedad y sin ánimo de reclamarlos». La regla, enmarcada en la regulación de la gestión de negocios ajenos, se dirige a la obtención de un resarcimiento por parte de quien presta alimentos sin estar obligado a ello ${ }^{45}$. Sin duda posible, la acción de repetición no se extiende a las obligaciones que surgen por imperativo de la filiación o de la patria potestad, y mucho menos entre ambos progenitores como es el caso presente, pues no se cumple ninguno de los presupuestos que determinan su aplicación. Esto es, ni los satisface un extraño, pues los ha prestado (en menor cuantía que la que correspondería) el otro progenitor, ni puede alegarse el desconocimiento de la obligación que le incumbe al incumplidor, al derivar la misma directamente de la filiación ${ }^{46}$.

Sería posible, si se trata de un matrimonio, que en el caso de no cumplir con su obligación uno de los padres acudiera el otro a los Tribunales en uso de la facultad que le confiere el artículo $1318 \mathrm{CC}$, en su párrafo segundo: «Cuando uno de los cónyuges incumpliere su deber de contribuir al levantamiento de estas cargas, el juez, a instancia del otro, dictará las medidas cautelares que estime convenientes a fin de asegurar su cumplimiento y los anticipos necesarios o proveer a las necesidades futuras». No obstante, la reclamación llevada a cabo por esta vía tan solo permite garantizar el pago de las cantidades futuras, pero nada resuelve sobre las cuantías pasadas.

Enlazando con esta situación, como ya se ha apuntado repetidamente, en los casos de solicitudes de alimentos en el marco de los procedimientos matrimoniales, es doctrina reiterada de los tribunales la aplicación de la limitación temporal surgida del párrafo primero del artículo $148 \mathrm{CC}$, lo que no permite resarcimiento alguno por la vía de la negación de efectos retroactivos.

${ }^{45} \mathrm{El}$ voto particular considera esta regla como una de las soluciones desarrolladas por el ordenamiento para mitigar los problemas que las situaciones de pendencia pueden generar sobre la seguridad jurídica.

${ }_{46}$ Precisamente por esta circunstancia es complejo resolver el tema de la solicitud de alimentos con efecto retroactivo en el caso de las acciones de reclamación de filiación, al poder desconocer el progenitor determinado por el ejercicio de la pretensión la filiación en cuestión. Otra cuestión, planteada por la doctrina y no resuelta con claridad, es la posible reclamación del hijo por los daños sufridos frente al progenitor por falta de reconocimiento voluntario cuando es conocedor de la paternidad. Sobre este tema en particular, ver PIZARRo WiLsON, C. (2006): «Responsabilidad civil por no reconocimiento voluntario del hijo de filiación extramatrimonial», en Daños en el Derecho de familia, Thomson Aranzadi, pp. 101 y ss. 
Sí existen ciertas sanciones o consecuencias dentro del ámbito familiar y sucesorio por el incumplimiento de la obligación de alimentar a los hijos. Concretamente, siguiendo el dictado del artículo $170 \mathrm{CC}$ la conculcación de los deberes inherentes a la patria potestad (y el de alimentar a los hijos participa de ese carácter conforme al art. $154,1 .{ }^{\circ} \mathrm{CC}$ ) puede ser motivo de privación total o parcial de aquella. Del mismo modo tal infracción puede ser causa justa de desheredación para el ascendiente o cónyuge por su descendiente o consorte, conforme a los artículo 854 y $855 \mathrm{CC}$; así como poder llegar a considerarse causa de indignidad calificándolo como un caso de abandono de los hijos encuadrable en lo dispuesto en el artículo $756,1 .^{\circ} \mathrm{CC}$. Ahora bien, tales privaciones de derechos tan solo servirán para reprobar la conducta del progenitor incumplidor, pero en nada interfieren en la satisfacción de la prestación no cumplida.

Otra cuestión diferente será acudir a una posible reclamación de daños, por la vía del artículo 1902 CC o por otro cauce, por los causados directamente al hijo con ocasión del incumplimiento del deber constitucional de alimentar a los menores. De lo que se trataría ahora no es de determinar las posibles acciones o reclamaciones que incumbieran al sujeto cumplidor frente al deudor incumplidor, sino de reflexionar sobre el posible ejercicio de una acción por parte del hijo por los daños causados por la falta de prestación de los alimentos debidos. La materia de las reclamaciones de daños en el marco de las relaciones familiares se presenta como un tema complejo y en el que los tribunales avanzan con suma cautela ${ }^{47}$, aunque en algunos aspectos concretos como los daños ocasionados a la salud, o los provocados por la inadecuada administración del patrimonio del hijo se contemplan sin especiales dificultades ${ }^{48}$.

47 Una visión general en FERRER I RIBA, J. (2003): «Relaciones familiares y límites al Derecho de daños», en Estudios Jurídicos en homenaje al Profesor Luis Díez-Picazo, T. II, Thomson Civitas, pp. 1837 y ss.

${ }^{48}$ Se reconoce por el Tribunal Supremo que el artículo 1902 CC es el cauce adecuado para la reclamación entablada por el padre que llega a conocer que no lo es y que demanda el resarcimiento de los alimentos pagados al supuesto hijo desde que se produce la ruptura matrimonial en la STS de 24 de abril de 2015 (RJ 2015\1915). La sentencia reviste gran interés por cuanto analiza las posibles vías de resarcimiento, negando, en contra de lo resuelto por algunas Audiencias y lo argumentado en el voto particular, la invocación del artículo $1895 \mathrm{del} \mathrm{CC}$, al no considerar que se trate de un caso de pago de lo indebido. Del mismo modo el contenido del voto particular resulta de gran interés por el análisis de la materia bajo las perspectivas actuales del Derecho de familia. 
No obstante, en el marco de los alimentos, entre la doctrina que se ha ocupado de la cuestión pueden encontrarse opiniones favorables al ejercicio de acciones por la no prestación del deber de asistencia a los hijos, bien por el incumplimiento de una obligación legal, $e x$ artículos 1090 y 1101 del Código civil ${ }^{49}$, bien en el marco de la responsabilidad extracontractual, si se cumplen los presupuestos necesarios para ello ${ }^{50}$.

Creo que la situación debe cuanto menos ser objeto de reflexión. Si en el marco de la obligación legal de alimentos entre parientes se plantea la posibilidad de ejercicio de acciones por la vía del artículo 1902 $\mathrm{CC}$ del alimentante frente al alimentista incumplidor por los daños que le hubiera ocasionado el no cumplimiento voluntario de su obligación - por ejemplo se menciona el caso de que hubiera tenido que endeudarse mediante la solicitud de préstamos para atender a sus necesidades vitales $-{ }^{51}$, a mayor abundamiento debería pensarse en los posibles daños causados al hijo por la no prestación de alimentos a los que tenía derecho desde su nacimiento.

Por otra parte, el recurso a conceptos como la pérdida de oportunidades podría llegar a tener reflejo en este tipo de reclamaciones, por cuanto, sin duda, el hijo que no ha recibido los alimentos a que tenía derecho, teniendo en cuenta que debe percibirlos por partida doble y en relación a la posición económica de ambos progenitores, podrá haber visto disminuidas sus posibilidades de desarrollo educacional o profesional $^{52}$. Se trata de categorías que se relacionan habitualmente con los daños ocasionados por falta de reconocimiento de filiación, pero en los que podría pensarse como medio de satisfacción de la falta de efectos retroactivos de la obligación de alimentos.

49 En este sentido se manifiesta BARBER, ob. cit., p. 591.

${ }^{50}$ Concretamente lo considera de esta manera RodríGuez Guitián, A. M. (2009): Responsabilidad civil en el Derecho de familia: especial referencia al ámbito de las relaciones paterno-filiales, Thomson-Reuters Civitas, p. 126.

${ }^{51}$ Opinión sustentada por DelGado, ob. cit., p. 536, cuando se trate de un incumplimiento consciente del obligado. Manifiesta sus reservas a la postura expuesta GuTIÉRREZ BERLINCHES, ob. cit., p. 74, por el riesgo de pretender así el cobro de pensiones prescritas.

${ }^{52}$ Se ocupa de la cuestión Bustos Moreno, Y. (2012): «El resarcimiento del daño causado por la falta de reconocimiento en la filiación no matrimonial», en $L a$ responsabilidad civil en las relaciones familiares, Dykinson, Madrid, pp. 155 y ss. También Martín Casals, M. y Ribot Igualada, J. (2011): «Daños en Derecho de familia: un paso adelante, dos atrás», Anuario de Derecho Civil, abril-junio 2011, pp. 556 y ss., considerando tratarse de un daño patrimonial por haber podido tener recursos para gozar de una posición social y económica mejor. 
Sin duda posible al respecto, el supuesto objeto del ATC 301/2014 presenta puntos de interés de tal trascendencia que hubiera sido aconsejable haber admitido a trámite la cuestión como cauce de oportunidad para que el Tribunal, a la vista de los argumentos esgrimidos por las partes, hubiera podido profundizar en su desarrollo y consideración.

\section{BREVES CONCLUSIONES}

El análisis del Auto 301/2014 plantea numerosos aspectos sobre los que reflexionar, tanto en cuanto a lo resuelto en el fallo como en el meditado voto particular.

El texto sobre el que se plantea la cuestión de inconstitucionalidad, creo que adecuadamente formulada por el Juzgado, afecta a la extensión y contenido de la obligación constitucional de alimentar a los hijos menores, consagrada en el artículo 39.3 CE, que se ve reducida y limitada por su encuadre en los rígidos presupuestos del artículo 148, párrafo primero del Código. Sin duda posible al respecto, la posición de los Tribunales trunca el derecho a ser alimentado que asiste a los hijos menores, centrándose la atención de aquellos más en el tratamiento del posible derecho a recobro del progenitor alimentante que en la situación en la que queda el hijo a quien se priva de ser acreedor frente a ambos padres.

La regla en cuestión no solo es preconstitucional, pudiendo considerarse tácitamente derogada respecto a las reclamaciones atinentes al cumplimiento de lo dispuesto en el artículo 39 de la CE, sino que forma parte de la redacción original del CC, dirigiendo su ámbito de aplicación a una clase de obligaciones de fundamento, contenido y extensión diferentes a las que incumben a los padres respecto de sus hijos. En aquellos casos cobra pleno significado la limitación temporal y la negación de carácter retroactivo, apelando a la que se trata de satisfacer alimentos presentes y futuros, no pretéritos, y al posible desconocimiento del deudor de la circunstancia de tener que atender a las mismas.

El Tribunal Supremo, a la hora de enjuiciar las demandas de alimentos a progenitores, en el marco de procedimientos matrimoniales y de reclamación de filiación, podría haber determinado no ser de aplicación la rigidez de lo dispuesto en el artículo $148,1 .^{\circ} \mathrm{CC}$, por considerarlo contrario al cumplimiento de la obligación constitucional de alimentar a los hijos menores, pues repetidamente ha destacado la especialidad y diferencia del sustento de estos hijos frente a la obligación legal de alimentos entre parientes. 
Como argumentos para proceder a una recta hermenéutica del precepto podrían los Tribunales apoyarse en el principio del interés superior del menor, formulado en la Convención de Derechos del Niño y en la Ley Orgánica de Protección del Menor como esencial y determinante criterio de interpretación al que puede acudirse por los jueces en la adecuada búsqueda del sentido correcto de las normas, principio que, por otra parte, el propio Constitucional ha reconocido como inspirador del contenido del artículo 39 CE.

El Tribunal debería haber admitido a trámite la cuestión de inconstitucionalidad, pues los argumentos esgrimidos presentan la solidez suficiente para considerarla viable, e incluso, avanzando un poco más, hubiera podido dictar una sentencia interpretativa, excluyendo del ámbito del rígido precepto los alimentos debidos a los hijos menores.

La seguridad jurídica, por otra parte, motivo prácticamente determinante de la inadmisión del planteamiento, no se ve comprometida en cuanto a la reclamación de los alimentos de origen convencional, en los que, como es habitual, la institución de la prescripción cumple la finalidad de preservar el respeto a la mencionada seguridad. No se observa motivo alguno que permita aconsejar un tratamiento más rígido para las pretensiones de alimentos que derivan de la Constitución y de la filiación.

Sin duda, estos resumidos argumentos, y otros muchos expuestos a lo largo de estas líneas, hubieran aconsejado la admisión a trámite del recurso.

\section{BIBLIOGRAFÍA}

Barber CÁrcamo. R. (2011): «Comentario al artículo 110», en Código Civil comentado, Cañizares laso, A., De Pablo Contreras, P., Orduña MoRENO, J. y VAlPUESTA FERnÁndEZ, R. (Dirs.), Vol. I, Civitas-Thomson Reuters, Madrid, pp. 110 y ss.

BERCOVITZ RODRÍGUEZ-CANO, R. (2015): «Un voto particular interesante en materia de alimentos», Revista Doctrinal Aranzadi Civil-Mercantil n. ${ }^{\circ} 1 / 2015$ parte Comentario (BIB 2015\718).

Bustos Moreno, Y. (2012): «El resarcimiento del daño causado por la falta de reconocimiento en la filiación no matrimonial», en La responsabilidad civil en las relaciones familiares, MORENO MARTíneZ, J. A. (Coord.), Dykinson, Madrid, pp. 129 y ss.

Cabezuelo Arenas, A. L. y Castilla Barea, M. (2011): «La obligación de alimentos como obligación familiar básica», en Tratado de Derecho de la Familia, YzQuierdo Tolsada, M. y Cuena Casas, M. (Dirs), vol. I, Aranzadi, Cizur Menor, pp. 193 y ss. 
CAÑIZares Laso, A. (2012): «Obligaciones familiares básicas», en Derecho de familia, DíEz-PicAzo GiménEZ, G. (Coord.), Civitas Thomson Reuters, Madrid, pp. 135 y ss.

CoвAcho Gómez, J. A. (1990): La deuda alimenticia, Montecorvo, Madrid.

Costas Rodal, L. (2015): «Novedades jurisprudenciales en materia de suspensión de la obligación de pagar alimentos a los hijos menores por ingreso en prisión del progenitor alimentante», Revista Doctrinal Aranzadi Civil-Mercantil, n. ${ }^{\circ}$ 9/2015, parte Comentario (BIB 2014\4432).

Cuena Casa, M. (2013): «Comentario al artículo 148», en Comentarios al Código Civil, Bercovitz Rodríguez-CAno, R. (Dir.), T.I, Tirant lo Blanch, Valencia, pp. 1493 y ss.

DíAz Revorio, F. (2000): «Interpretación constitucional de la ley y sentencias interpretativas», Repertorio Aranzadi del Tribunal Constitucional, n. ${ }^{\circ}$ 2/2000, parte Estudio, BIB 2000\6.

Delgado EChEVERríA, J. (1991): «Comentario del artículo 148», en Comentario del Código Civil, T. I, Ministerio de Justicia, Madrid, pp. 534 y ss.

EChevarría DE RADA, M. ${ }^{a}$ T. (2011): El contrato de alimentos en el Código Civil, Universidad Rey Juan Carlos, Madrid.

Espín Espín, D. (1984): Comentarios a la Constitución Española de 1978, T. IV, Edersa, Madrid.

FERRER I RIBA, J. (2003): «Relaciones familiares y límites al Derecho de daños», en Estudios Jurídicos en homenaje al Profesor Luis Díez-Picazo, T. II, Thomson Civitas, pp. 1837 y ss.

Fosar Benlloch, E. (1981): Estudios de Derecho de Familia. T. I. La Constitución de 1978 y el Derecho de familia, Bosch, Barcelona.

GÁlvez Montes, F. (2001): «Comentario del artículo 39», Comentarios a la Constitución, Garrido de Falla, F. (Dir.), 3. ${ }^{a}$ edic., Civitas, Madrid, pp. 847 y ss.

GARCÍA DE ENTERRÍA, E. (1988): La Constitución como norma y el Tribunal Constitucional, Civitas, Madrid.

Gómez, Y. (1990): Familia y matrimonio en la Constitución de 1978, Congreso de los Diputados.

Gómez LAPLAZA, M. ${ }^{a}$ C. (2004): «Consideraciones sobre la nueva regulación del contrato de alimentos», Revista de Derecho Privado, marzo-abril 2004, pp. 153 y ss.

GuILARTE MARTÍN-CALERO, C. (2014): La concreción del interés del menor en la jurisprudencia del Tribunal Supremo, Tirant lo Blanch, Valencia.

GutiÉRrez Berlinches, A. (2003): Los procesos de alimentos, Marcial Pons, Madrid.

JiMÉNEZ CAMPO, J. (1977): «Qué hacer con la ley inconstitucional», en La sentencia sobre la constitucionalidad de la ley, Cuadernos y debates, n. ${ }^{\circ}$ 66, Tribunal Constitucional, Centro de Estudios Constitucionales, Madrid, pp. 15 y ss. 
JimÉnEZ MuÑOZ, F. J. (2006): «La regulación española de la obligación legal de alimentos entre parientes», Anuario de Derecho Civil, abril-junio 2006, pp. 743 y ss.

Martín Casals, M. y Ribot Igualada, J. (2011): «Daños en Derecho de familia: un paso adelante, dos atrás», Anuario de Derecho Civil, abril-junio 2011, pp. 547 y ss.

MARTínez RodríGueZ, N. (2012): «Alimentos para hijos menores cuando se reclaman en un proceso judicial por ruptura de relaciones entre sus progenitores. Aplicación del artículo 148.1 del Código Civil», Cuadernos Civitas de Jurisprudencia Civil, número 89, mayo-agosto 2012, pp. 157 y ss.

- (2002): La obligación legal de alimentos entre parientes, La Ley, Madrid.

Medina Guerrero, M. (2000): en CaAmaño Domínguez, F., Gómez Montoro, A. J., Medina Guerrero, M. y Requejo Pages, J. L., Jurisdicción y procesos constitucionales, 2. ${ }^{\text {a }}$ edic., McGraw Hill, Madrid.

Ortiz Herrera, S. (1997): «Articulación del Tribunal Constitucional y del poder judicial en la labor interpretativa de la Constitución. Especial referencia a las sentencias interpretativas del Tribunal Constitucional», Boletín de la Facultad de Derecho, n. ${ }^{\circ}$ 12, Universidad Nacional de Educación a Distancia.

Padial AlBás, A. (1997): La obligación de alimentos entre parientes, Bosch, Barcelona.

- (2011): «La obligación de alimentos», en Derecho de la Persona, RAVETLlAT BAllesté, I. (Coord.), Bosch, Barcelona, pp. 137 y ss.

PIZARRo Wilson, C. (2006): «Responsabilidad civil por no reconocimiento voluntario del hijo de filiación extramatrimonial», en Daños en el Derecho de familia, De Verda y BeAmonte, J. R. (Coord.), Thomson Aranzadi, pp. 101 y ss.

ReAl PÉrez, A. (2000): «Comentario al artículo 148 CC», en Comentarios al Código Civil, Rams Albesa, J. (Dir.), T. II, vol. 2. ${ }^{\circ}$, Bosch, Barcelona, pp. 1454 y ss.

Ribot Igualada, J. (1998): «El fundamento de la obligación legal de alimentos», Anuario de Derecho Civil, julio-septiembre de 1998, pp. 1105 y ss.

- (1999): Alimentos entre parientes y subsidiariedad de la protección social, Tirant lo Blanch, Valencia.

Rodríguez Guitín, A. M. (2009): Responsabilidad civil en el Derecho de familia: especial referencia al ámbito de las relaciones paterno-filiales, Thomson-Reuters Civitas.

RudA GonzÁlez, A. (2014): «Comentari del artículo 237-4», en Comentari al llibre segon del Codi Civil de Catalunya, EgEA y Fernández, J. y FERrer i Riba (Dirs.), FARnós i Amorós, E. (Coord.), Atelier, Barcelona, pp. 992 y ss.

Sierra PÉrez, I. (2001): «Comentario al artículo 148», en Código Civil comentado, Cañizares Laso, A., De Pablo Contreras, P., Orduña More- 
nO, J. y Valpuesta Fernández, R. (Dirs.), Vol. I, Civitas-Thomson Reuters, Madrid, pp. 747 y ss.

Tena Piazuelo, I. (2015): La prestación de alimentos a los hijos tras la ruptura de pareja: pensiones, gastos, vivienda. Doctrina y jurisprudencia, Aranzadi, Cizur Menor.

ZAGREBElSKY, G. (1988): La giustizia costituzionale, Il Mulino, Bolonia. 
